\title{
ERRATUM
}

\section{Erratum to: Albiglutide Does Not Prolong QTc Interval in Healthy Subjects: A Thorough ECG Study}

Borje Darpo $\cdot$ Meijian Zhou $\cdot$ Jessica Matthews $\cdot$ Hui Zhi $\cdot$

Malcolm A. Young $\cdot$ Caroline Perry $\cdot$ Rickey R. Reinhardt

To view enhanced content go to www.diabetestherapy-open.com

Published online: July 18, 2014

(c) The Author(s) 2014. This article is published with open access at Springerlink.com

Erratum to: Diabetes Ther (2014) 5:141-153

DOI 10.1007/s13300-014-0055-1

The authors of the above mentioned manuscript would like to make the following clarification. The associated ClinicalTrials.gov registration number for this GlaxoSmithKline trial "Albiglutide Thorough ECG Study in Healthy Volunteers" was inadvertently omitted within the previously published results. The full registration number for this trial is NCT01406262.

The online version of the original article can be found under doi:10.1007/s13300-014-0055-1.

B. Darpo $(\bowtie)$

Department of Clinical Sciences, Karolinska Institute, Division of Cardiovascular Medicine, Danderyd's Hospital, Stockholm, Sweden

e-mail: borje.darpo@telia.com

B. Darpo · M. Zhou

iCardiac Technologies, Rochester, NY, USA

J. Matthews · H. Zhi · M. A. Young

GlaxoSmithKline, Research Triangle Park, NC, USA

C. Perry · R. R. Reinhardt

GlaxoSmithKline, King of Prussia, PA, USA
Open Access. This article is distributed under the terms of the Creative Commons Attribution Noncommercial License which permits any noncommercial use, distribution, and reproduction in any medium, provided the original author(s) and the source are credited. 